\title{
Professional Education for Traditional Crafts in Kosovo
}

\author{
Kastriot Haxhiu, PhD Cand. \\ Professor Technical Secondary School "Nexhmedin Nixha", Gjakova
}

\begin{abstract}
Youth vocational education belongs to the general sphere of an individual education, having in mind that regular education is not a conclusion but an ongoing process. Knowledge is not limited to or has any limits whatsoever, but simply are one of the conditions to materialize lifelong education. Requirements to approach the European community dictate the need for the Kosovar society in general and its youth in particular must continue their education to meet the challenges and obstacles of life are changing rapidly. The use of new technologies is one of the most dramatic changes in professional education. Along with this new reality that is before us young people must inevitably continue to track participation in vocational education as one of the alternatives for easier access to employment and development their career. Qualified professions and crafts are those jobs or activities that produce products made by individuals or providing specialized technological services. Qualifications for these specialized professions and crafts are obtained through professional education based on concrete programs. To motivate young people to attend a vocational training as a prerequisite to reach easily to the labor market, the Kosovar state needs a reforming flexibility in curriculum reorientation of vocational training. Therefore, result oriented efficient training programs must be catalyst for young Kosovar today in continuing education in professional schools.
\end{abstract}

Keywords: Vocational education, vocational programs, curricula, youth, crafts.

\section{Purpose of the study}

The overall goal of this study is to identify current opportunities to change the vocational programs near Vocational Training Centre's and vocational higher secondary, for young people who have no profession or do not attend tertiary education, with the aim of undertaking initiatives to improve vocational training services in the country. Basic purpose is the revitalization of traditional crafts being adapted to the technology of the time and stimulates the dialogue between the parties involved in this structure.

\section{Methodology}

The paper was conducted including the analysis of relevant literature (articles in various electronic and daily Kosovar magazines). Field meetings with experts and institutions, sample design and methodology of the survey and its implementation through interviews and questionnaires

\section{Preamble}

Education is one of the most important areas of every society and every system. Education is a sector that not only leads the society, but also strongly affected by it and the changes that occur to it. The fact that education systems are in permanent change, it serves to better adapt to social change and move with the pace of time, always to the benefit of economic and social development.

Vocational education affects labor force participation and has broader social benefits. Higher education significantly advances the chances for employment and enables their involvement in the labor market. The job market today requires professionals. Traditional products and the technological evolution have increased the requirement for professional workers. 
How prepared is a Young Kosovar today for these technological developments? What our professional schools have to offer? Do professional programs for traditional crafts? Basically there are some questions which young and Kosovar Artisan responded with direct interviews.

Not so welcoming responses are obtained from the youth and "artists" of traditional occupations. Reasons and factors should be found and examined. Analysis for strategic change program should be a national priority alongside other legal reforms.

Ministry of Education Science and Technology (MEST) in Kosovo, has taken some initial steps, such as the development of curricula, the construction of school buildings, the regulation of professional teaching staff and the opening of various professional directions. But these steps have already stagnated. Replacement of generations who complete upper secondary schools is yearly, they require training that enables learning a craft which is competitive for the labor market.

Traditional crafts in Kosovo are fading away day by day. According to those involved in this work, crafts have turned into a non-profitable work. This may be one of the reasons why young people do not want to continue the trade of their ancestors

The stories of European countries show that many of these states jealously preserve traditional crafts. France has a small village with artisans, in which the whole village is engaged in making characteristic hats. In Italy there is also a small village, and they all are in engaged in ceramic works. Albania has a historical city which mainly deals with the copper and clay works. Turkey has many places where traditional crafts ensure a good life and help the country's economic development, especially the tourist sector.

As commercial competition globally is increasing rapidly, new technologies have created an era of information which reflects the way how different organizations, including educational institutions generate and administer their services, changing ways and forms of communication and use of information. Integration of Information and Communication Technology (ICT) in vocational education has been one of the main aspects of the development of education of the population of European countries.

An inevitable aspect of this new reality of the knowledge society is the need to change the approach to vocational education, knowing that the participation of adults in Kosovo in professional education, compared with European countries remains low, due to many factors and circumstances.

Therefore, a co-operation between traditional crafts and new technology could motivate a young Kosovar to continue his personal education in higher vocational secondary schools.

Professional trainings for traditional crafts

The Government of the Republic of Kosovo is committed to upholding the right of every person to be educated within a choice of lifelong learning, regardless of gender, age, religion, ethnicity and disability (Education Strategic Plan Kosovo 2011-2016, pg. 54).

Besides attention and support given to vocational training in recent years by the Kosovo government, unfortunately, as in the past, politicians or governments, have done nothing but continued in line with the policy of rhetoric upholding the opinion that youth needs a profession.

Various crafts in sectors such as construction and decoration of the interior, metal works, work with wood and plastic, clothing, textiles and leather, food industry, chemical sector and the sector of cleaning, maintenance and management of computer networks, web design, graphic design are some of the requirements of the market today. Qualifications for these specialized professions and crafts are obtained through vocational training.

Occupations like farming, agriculture, fishing, handicrafts, soft industry are also among professions that have greater employment opportunities in Kosovo. Not any well-thought policy that can bring long-term development was implemented in terms of preparation of young people for career profession. 
Question: How much are the traditional crafts endangered and what is the reason?

I will pick out several quotations by historians, jurists and experts of heritage in Gjakova: "In the Grand Bazaar (Qarshia e Madhe) of Gjakova, since its establishment, dozens of crafts were practiced, ranging from gunsmiths, goldsmiths, kettle crafts, leather workers, tailors, embroiderers, carpenters, fez makers, , saddlery, albanian traditional shoes(, opinga makers), etc. Most of them have already ceased their activity". "Grand Bazaar of Gjakova was also the main center, the most powerful, economic city. " " Sometimes personally I have been companion and translator of delegations, tourists from Italy, Germany, France, England, Turkey, America, Israel, etc. , None was left to leave without a lunch, dinner, gifts, souvenirs, national or religious garments, and they slept in hostel's" ("Koha Ditore" newspaper, Gazmend Doli, p. 26 ).

There are similar cases in all other cities of Kosovo like in Prizren, razor crafts,. . . Pristina, Peja (Craft tray (zeja tabakeve)is among the best known and the oldest, not only in Kosovo but all over the Balkans ), Gjilan as well. . . each of these regions has crafts that are characteristics of those settlements.

In this indifference or disregard to these professions have influenced and still are, a number of factors. Therefore it is common to analyze the factors and circumstances that we think have an impact on the establishment of greater interest of adults, for participation in vocational education.

Lack of full functional relationship between ministries or municipal departments regarding education and training of adults (despite several late attempts, which come as a non-fussy reaction of Kosovar institutions) is considered as the primary factor. Lack of youth support from family and community, because of the social attitude towards traditional crafts which are seen as non-profit and belonging to the past, it's the very next factor. Lack of strategy on the creation of a school program on craftsmanship in vocational schools is an essential factor of no interest from the government for cultural heritage. These are three basic reasons why traditional crafts are being vanished. All these come from direct interviews with the surveyed population.

Here's an idea: vocational schools have a different nature from mainstream schools. To answer this challenge, we need to create a somewhat different world regarding vocational schools otherwise one can be left away. Union of vocational education with vocational formation can materialize it, accomplish it, connect it with business, enhance students and enable them to be employed at the businesses or enterprises where they have completed practice.

Creating a center of craftsmen is seen as the only salvation for ancient crafts, which are on the verge of bankruptcy, because they cannot withstand the competition, which comes as a result of technological development. Besides, the compilation of the curricula plan on these crafts depending on the specifics of Municipalities would be a push towards saving these traditional crafts in correlation with the awakening an interest of young people for these professions which are directly related to market work.

"Taking into account current trends, the establishment of the center of craftsmen, in which space every tourist would have the opportunity to see the creation of souvenirs and handicrafts from the craftsmen directly, would be a right step towards conservation of Prizren tradition, "said a Prizren craftsman. (http://koha. net/)

The opening of the craftsmen is not a big problem for the government, but to ensure its continuity it needs a professional infrastructure and a panel in various fields. The opening of classes in vocational high schools with crafts and traditional crafts, development of adequate curricula and cooperation with the respective communities would be an initial initiative to rescue from bankruptcy these historic old crafts that represent national identity. Municipalities would have full autonomy in the selection of craft profile, based on market requirements and local artistic heritage.

Requirements of the European Union (EU) call for the Kosovo society and institutions dealing directly with vocational education in particular to pay greater importance to training and youth training. Additionally Kosovo is required to show its cultural heritage within the EU countries. 


\section{Achievements and weaknesses of education in Kosovo}

In postwar Kosovo are taken very big steps in building school infrastructure. Tangible investments have taken place everywhere. With the help of international donations it has managed to reach projections and realized a very solid educational system in terms of educational facilities and capacity development programs, as well as in the preparation of teachers' qualifications. Some of the actions undertaken were not realized until the end, stagnation which has created gaps in educational and vocational training in particular not harmonizing training programs with market demand and also because of the lack of money, therefore (according to officials of relevant ministries) there is no constant research of the market needs nor innovations in the involvement of new technological programs.

Among the weaknesses in vocational education in Kosovo (around 10) I will present only four essential ones:

Internship programs are not designed through genuine working partnerships between schools Vocational Education and Training (VET) and employers.

Low participation of (VET) schools in community programs.

There is no clear vision of who is responsible, and who can provide support and how to organize professional practice.

VET Schools lack of promotional materials to reinforce their message when they meet with employers to create new partnerships.

(Strategic plan for education in Kosovo 2011-2016, p. 12)

Under this plan lacks the program for vocational training curricula for traditional occupations. Lack of professional literature for vocational schools is more than evident because in itself creates a barrier.

Kosovo is a small country, but with many values, with capable people, gifted and with a lot of will, eager for change and progress. It needs an institutional boost for periodical advancement.

Development of a plan for the preservation of crafts through vocational training is a contemporary new concept which can significantly increase the interest of young people to participate in vocational education. Precisely through its vocational education and continuing training of young people in various educations formal and informal will have a significant impact in reducing unemployment in Kosovo which is currently the highest in the Balkans in a scale of $35 \%$.

Heritage significantly affects tourism development, tourism creates jobs. Therefore crafts are part of the development process and reduce the high rate of unemployment.

Many older German traditions still flourish today. They are preserved with love and full of fanaticism by artisan craftsmen and small manufacturers, and have undergone a journey from generation to generation. Traditions like these are often intertwined between arts and crafts. We are looking at traditional craftsmen we remain amazed how modern can be old skills. Dual learning system enables some of the traditional crafts get acquired through vocational training.

\section{Data on labor market}

It is known that, in the past decade countries that have had success in the number of new employees or reducing youth unemployment in the country are the ones that have had vocational education closely interconnected with the labor market. Unemployment is a challenge not only in Kosovo, but also in the European countries.

Kosovo has the youngest population in the region, the average age in 2011 was estimated to be 30.2 years old, while in the region is 37.4 years old, in Europe 40. 6 years old (Statistical Yearbook of the Republic of Kosovo, Pristina, May 2014). The number of pupils who have abandoned schools for 2013/2014 is 3067 students. (Statistics Agency of Kosovo, Pristina, December 2014). 
From 15-24 years old age group has the highest unemployment rate of the total population of $55.9 \%$. Of a greater concern is the high percentage of female gender with $68.4 \%$ against $50.4 \%$ of men. Also high and even worrisome is the percentage of young people who are unemployed or do not attend school or do not attend any training, a figure $35.3 \%$ of the total number of population economically active work in Kosovo, the gender ratio $40.9 \%$ female to $30.0 \%$ male. (The results of the Labor Force Survey 2013 in Kosovo, November 2014, Pristina)

Kosovo society respectively its government in cooperation with all relevant bodies responsible for economic development must find a mechanism that gives young people a craft to access the labor market. Nor could they not become lawyers, or astronauts, or physicists. They should take a specific vulnerable craft, which makes access to the labor market. The traditional crafts and artisan may have an alternative that provides dual results, professional education on the one hand and the preservation of traditional crafts on the other side. With these possibilities the cultural past of one of the youngest countries in Europe's will be highly enforced.

I believe that this step helps Kosovo to better integrate professional education with the countries development plan and at the same time motivates young people to vocational education.

\section{Support from MEST and other factors}

These traditional craft and culture have raised our awareness and cultural level. We must preserve the traditional part and also redirect it to future generations, as new generations who come after us. Therefore, these craft must be supported and assisted in their development. MEST should think to create a class for traditional crafts in vocational schools in Kosovo. Results of the survey showed that the current situation is not favorable, while the future seems to be even worse for traditional manufacturing activities.

Opening profiles for traditional crafts in vocational schools would be a developmental approach, which will also raise awareness and steer the mobilization of other state institutions and society to support vanishing crafts. In this conformation it will also motivate young Kosovar to pursue these educational profiles. This fusion is able to realize a socio-economic potential, cultural and historical center on real national tradition. School curricula should be oriented to three school years, while training programs for periods of 6 months, 9 months or even longer depending on the product and the level of certification.

All these products should be in the form of souvenirs produced by pupils or interns and must have a fixed center, where they will be offered directly to the market and tourists, and there are plenty in Kosovo. It is necessary that vocational schools and vocational training centers (VTC's) have the support of business.

To support this new education strategy in schools - vocational centers it is necessary to be in compliance with professional skills curriculum that would produce antique products and the market needs people with these skills. Therefore, the role of business in this skill and certification process of youth would provide the market with a professional worker in a near future?

Regarding the role of the business, his voice has not been heard so far as required because of the lack of mechanisms to absorb their contribution. They would have been instructors of vocational schools or professional instructors practices regarding the profiles in question, because they are very good technicians, highly skilled artisans.

Vocational education and training related to business, enables students / trainees and gives them later on the opportunity to work at that business where they performed professional practice. In the case of EU countries, the ministries of the cantons (Lander) have the competence for vocational education therefore a bill should be build that would solve some specific problems. . This law should be formulated to crystallize things and is obliged to respond to the new reality. Of course there should be included fiscal incentives or subsidies for various businesses in grants, but the state does not hold the total financial burden. Private business should also invest out of their pockets for the benefit of all, and it would be very philanthropic to think differently. In all countries of the world it is regulated by law, therefore, Kosovo needs such a law. As a result of the survey, the business is pro to joint to this structure but it is also interested to profit from the investment it is doing for the good of all, especially in creating conditions for youth training and employment. 
Prime Minister Isa Mustafa has promised the abolition of customs duties on machinery required for the production of various crafts, and stressed that the government he will head will enable artisans to receive loans, while loan interest basis will be compensated by the government (http://www. kosovapress. com/). This should not remain just as an electoral promise but should be implemented, as soon as possible.

"Given the immense scientific, technological and socio-economic development, either in progress or envisaged, which characterizes the present era, particularly globalization and the revolution in information technology and communication, education should be a vital aspect of the educational process in all countries'(UNESCO, 2001). The support for these educational profiles - can arrive also from IT experts creating a database that links all institutions, engaged in this activity. Opening a web page (in several languages) with comprehensive information on professional training for traditional crafts would have an electronic marketing character and proportions out of the Kosovo borders. Electronic information system would also increase the interest of other international factors to invest in traditional vocational education in the country.

Developing a manual which would include all historical data on traditional crafts in Kosovo, their role and importance today would circle mosaic of support of community for traditional vocational education. Means of visual information would have positive marketing effects.

\section{Organizational structure}

Cooperation supports the reformation of vocational education and training in Kosovo, reinforces the importance of vocational schools, and increases the production of traditional handicrafts in Kosovo. Professional handicraft teachers from Kosovo, even nationwide territories, would transmit their knowledge to new applicants and will preserve the cultural heritage of Kosovo.

Organizational cooperation structure should be more stable with the sole purpose the young in the center of it. Compilation of curricula for traditional crafts in the form most suitable for the labor market and conform to EU standards has essential preconditions. Giving full autonomy Municipal Assemblies on vocational schools, research and selection of the traditional craft of the latter in cooperation with the CVT serve as continuance of the system. Assistance and support of the business sector in training programs and craftsmanship center and government support for businesses can be a very good starting point to save traditional crafts in Kosovo and to motivate young people to this type of education. Over time this organizational structure can be expanded and enriched depending on the time and development perspective. Any professional suggestion would encourage debates for the countries benefit in culture, education and history.

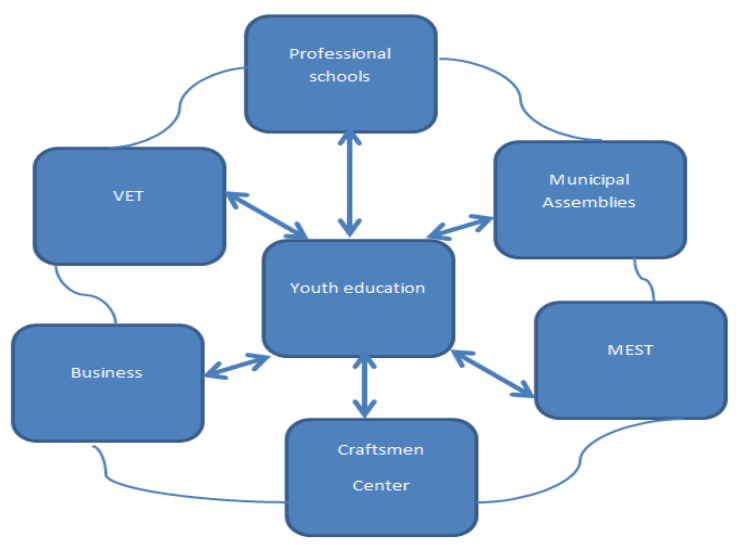

Figure : Organizational structure 
This cooperation must be accompanied by a legal act which would exactly clarify legal obligations and liabilities of each institution involved based on the norms of the country and conform to international standards. Only as such it can succeed.

\section{Conclusion}

Kosovo already has a structure of professional training and education in general, but it does not truly represent some of the economic needs as exist in all EU countries. Despite the improvement of VTC infrastructure and vocational schools, the essential problem remains the lack of strategies and programs that the market demands today, which is the weakest link in the chain of reforms to vocational training and education.

All human activities, including those performed within the scope of the curriculum, take place at a certain time, within a context. Development of curricula for professional training in traditional products in vocational schools, and the development of such a program for the VET would be crucial for the survival of traditional crafts in Kosovo.

Kosovo invests only $4.9 \%$ of its budget on education, compared with an average of $6 \%$ in countries with high income level. (Source: MEST: Educational Indicators in Kosovo, 2009-10, 2010-11 and 2011-12 June 2013, p. 81). This will be a great challenge for Kosovo society, based on its revenue, but if you look and evaluate the young Kosovar and think about the prospect on his side, and follow the inherited heritage over centuries, this will be one of the best decisions for the community and could bring freshness to the countries in the region.

This step will greatly reduce unemployment in the country, no matter the extent it has, in the same time it would bring awareness and motivate the youth to be trained for a traditional craft.

Construction of a partnership between countries of the region, in order to stimulate the revitalization of heritage and the local economy will be an additional motivation. The combination of handicrafts with technologies of the time would be a fantastic combination of XXI century towards the economic development of the country, having unemployment reduction a final result.

The engine of the country's development is and must be the professions, which luckily recent years are having an increased attention, so I hope that even a professional orientation on crafts tradition will be considered by the executive and legislative body of Kosovo and will be welcomed by the youth. Supporting the international factor with their experiences will strengthen far more the true meaning of this process.

\section{References}

Scholars for Education, World Education and Pedagogy Depository- A group of Authors, Tirana. Plejad, 2008

Rosemary A. Thompson, Professional School Counselling, Best practise for working in the schools, Third Edition, Taylor \& Francis Group, New York, 2012.

Simon. J. (2000). Developing decision making skill for business. Harper and Row. New York

Municipal Assembly Gjakova, scientific workshop, Gjakova and the surrounding topology, Gjakova, 2002

Matthews, B. \&Ross, L. (2007). Metoda e hulumtimit. CDE. Tiranë

\section{Magazines \& Articles \&Publications}

Labour Market and unemployment in Kosovo, Research paper, Riinvest, January 2003, Prishtina.

The results of the survey for workforce in Kosovo, 2009, Prishtina, November, 2010

Kosovo Statistical Agency, 31/December/2012. 
The Department of Work and Employment, Prishtina, 2013.

Eurofound 2012, NEETs - Young people not in employment, education or training: Characteristics, costs and policy responses in Europe, Publications Office of the European Union, Luxembourg.

The Republic of Kosovo Statistical Yearbook, Prishtina, May 2014.

Kosovo Statistical Agency, Prishtina, December 2014. .

Education Strategic Plan Kosovo 2011-2016

The results of the survey for workforce in Kosovo, 2013, Prishtinë, November, 2014.

A history of vocational education and training in Europe. From divergence to convergence. Thessaloniki. 2014. Cedefop

Electronic sources

https://ask. rks-gov. net/

https://ask. rks-gov. net/arsimi

http://www. kosovapress. com/

http://koha. net/

http://botasot. info/reportazhe/

http://www. kultplus. com/

http://pjeterbudi. com/kolegji/files/Revista_Studentore_nr_1_2009.pdf 